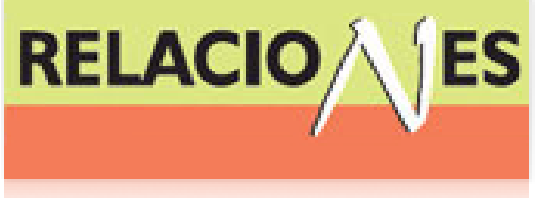

Relaciones. Estudios de historia y sociedad ISSN: 0185-3929

relacion@colmich.edu.mx

El Colegio de Michoacán, A.C

México

Trujillo Bretón, Jorge Alberto

Los excesos del deseo. Incontinencia y violencia sexual contra niños y jóvenes en Jalisco, 1885-1911

Relaciones. Estudios de historia y sociedad, vol. XXXII, núm. 127, 2011, pp. 153-194

El Colegio de Michoacán, A.C

Zamora, México

Disponible en: http://www.redalyc.org/articulo.oa?id=13719806006

Cómo citar el artículo

- Número completo

- Más información del artículo

Página de la revista en redalyc.org

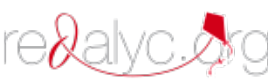

Sistema de Información Científica

Red de Revistas Científicas de América Latina, el Caribe, España y Portugal

Proyecto académico sin fines de lucro, desarrollado bajo la iniciativa de acceso abierto 


\section{Los excesos del deseo. Incontinencia y violencia sexual contra niños y jóvenes en Jalisco, 1885-1911}

Jorge Alberto Trujillo Bretón*

UNIVERSIDAD DE GUADALAJARA

La violencia sexual en el Jalisco porfiriano tuvo características singulares y formó parte de una violencia de género que afectó principalmente a niños y jóvenes de ambos sexos. Mientras este tipo de violencia la sufrieron mayormente mujeres jóvenes, víctimas de su círculo familiar y cercano, los varones, aunque en reducido número, llegaban también a ser violados en espacios abiertos o anónimos por individuos que los llegaban a superar en edad, fuerza y hasta en número. Estupros, violaciones, raptos, y aún incestos fueron un problema principal que llegó a engrosar la estadística criminal y ocupó, en su conjunto, un lugar principal sólo superado por los delitos de sangre y los económicos. Una violencia sexual que era contraria a lo representado en el discurso propio de la moral sexual porfiriana que alertaba sobre todo a los jóvenes de aquellos vicios y peligros a los que podían enfrentar y que eran contrarios a su formación como ciudadanos que debían ayudar a forjar una sociedad moderna.

(Infancia, juventud, violencia sexual, violencia de género, delito, homosexualidad)

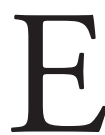

ste ensayo pretende exponer y explicar, a través de la historia sociocultural del delito, y auxiliado por el concepto de violencia sexual, los abusos de este tipo realizados contra niños y jóvenes en Jalisco desde 1885, año en que se decretó su primer código penal, hasta 1911 en el que se derrumbó la dictadura del general Porfirio Díaz. Atiende de manera particular, por un lado, el discurso que criticaba ciertos comportamientos sexuales contrarios

*jalberto55@hotmail.com 
a los ideales del matrimonio y, por otro, las prácticas ilegales mencionadas. Discursos que aparecían con cierta periodicidad en la hemerografía de la época, y prácticas que se exponían reiterativamente en el expediente del ramo criminal.

Ya que este ensayo tiene por objeto de estudio a los niños y jóvenes es importante referir que los primeros han ocupado un lugar especial y relativamente reciente dentro de la historiografía contemporánea, ya que ignorados por demasiado tiempo por las ciencias sociales y humanas fueron estas mismas las que los han venido rescatando del olvido y que se han significado por impulsar el estudio de este tipo en América Latina ${ }^{1}$ y en México. ${ }^{2}$

A fin de distinguir las diferencias de edades entre infancia y juventud, y que han representado un problema no sólo de carácter biológico, psicológico, cultural, legal, educativo, de género y hasta histórico, además de ser una antigua preocupación, ${ }^{3}$ este trabajo toma como primer referente el código civil de Jalisco (1875) que establece como edad mínima para contraer matrimonio los 12 años en el caso de las mujeres, y los 14 en los hombres. Hasta antes de cumplir esas edades tanto mujeres como varones pudieron ser considerados como nińos, aunque vale la pena mencionar que para un escritor decimonónico como lo fue José Joaquín Fernández de

${ }^{1}$ Los trabajos publicados sobre la historia de la niñez en América Latina son todavía más recientes, un ejemplo de ello es: la Historia de la infancia en América Latina que coordinaron Pablo Rodríguez y María Emma Mannarelli, y que cubre desde el periodo prehispánico hasta nuestros días. Este trabajo convierte a los niños en sujetos visibles y ayuda a hacer comprensible su significado en nuestros países. Pablo Rodríguez y María Emma Mannarelli, Historia de la infancia en América Latina, Colombia, Universidad del externado de Colombia, 2007.

${ }^{2}$ Algunos de los últimos trabajos para el caso de México son: Alberto del Castillo Troncoso, Conceptos, imágenes y representaciones de la niñez en la ciudad de México, 18801920, México, El Colegio de México, 2006; María de Lourdes Herrera Feria, Estudios sociales sobre la infancia en México, México, Benemérita Universidad Autónoma de Puebla, 2007; Antonio Padilla, Alcira Soler, Martha Luz Arredondo y Lucía M. Moctezuma, coords., La infancia en los siglos XIX y XX. Discursos e imágenes, espacios y prácticas, México, Casa Juan Pablos y Universidad Autónoma del Estado de Morelos, 2008; Susana Sosenski, Niños en acción. El trabajo infantil en la ciudad de México, 1920-1931, México, El Colegio de México, 2010.

${ }^{3}$ Vid Buenaventura Delgado, Historia de la infancia, 2a. edición, Barcelona, Editorial Ariel, 2000, 33. 
Lizardi, en su divertida novela Ensalada de Pollos, identifica a los llamados "pollos" como aquellos muchachos que se encontraban entre los doce y dieciocho años de edad, sumamente inmorales y con muy malas costumbres que los llevaban a frecuentar los prostíbulos. Si debemos considerar lo escrito por Fernández de Lizardi los niños de su época fueron aquellos que no rebasaban los doce años. ${ }^{4}$

En lo referente a la juventud, esto es todavía más problemático y a la vez más simbólico, pues si por un lado y conforme al mismo código, esta etapa bien puede partir de los 12 hasta cumplir los 30 ańos, edad límite en la que a la mujer soltera se le permitía abandonar el hogar paterno, es importante mencionar que la mayoría de edad se obtenía legalmente a partir de los 21 años, aunque había importantes limitaciones sobre todo para la mujer soltera. ${ }^{5}$ No obstante, este trabajo ha considerado como límite los 21 años, tanto en hombres, como mujeres, aunque es claro, como acertadamente lo señalan Giovanni Levi y Jean-Claude Schmitt, que es sumamente difícil definir la juventud "mediante criterios biológicos o con arreglo a criterios jurídicos. En todas partes y en todo tiempo sólo existe revestida de valores y símbolos". ${ }^{6}$

En cuanto a su estructura este ensayo está dividido principalmente en tres partes: la primera comprende el discurso moral y legal acerca del cuerpo y de los comportamientos considerados inmorales e ilegítimos; la segunda explica el concepto de violación y expone algunos casos representativos acerca de este tipo de delitos que afectaron a niñas y mujeres jóvenes; y, la última parte está enfocada a presentar algunos casos de violación a niños en el que se discute sobre la preferencia homosexual.

${ }^{4}$ Vid Jorge Alberto Trujillo Bretón,"La sociedad del buen tono" en revista Graffylia, año 6, número 8-9, primavera-otońo, Puebla, Facultad de Filosofía y Letras de la Benemérita Universidad Autónoma de Puebla, 2008, 155.

${ }^{5}$ Código Civil del Estado de Jalisco (1870), Guadalajara, Tip. De S. Banda, 13 de diciembre de 1875, 43-44.

${ }^{6}$ Giovanni Levi y Jean-Claude Schmidt, Historia de los jóvenes. I, De la Antigüedad a la Edad Moderna, Madrid, Taurus, 1996, 14. 


\section{ACERCA DE LA INFANCIA, LA JUVENTUd Y LA VIOLACIÓN}

Aunque este apartado no pretende ni mucho menos ser exhaustivo acerca de los estudios realizados sobre el pasado de la infancia es importante al menos mencionar un par de ellos por la importancia que tiene tanto la edad como la violencia para este ensayo. El primero de ellos y que es el pionero en este tipo de estudios es El niño y la vida familiar en el Antiguo Régimen (1973) de Philippe Ariés en e1 que su autor explica que la infancia ha sido parte de la construcción cultural que las sociedades europeas realizaron de ésta, y que no existía una precisión para identificar la edad ni las características del niño. ${ }^{7}$ Este primer problema de la edad en los niños ha sido ampliamente debatido y también matizado por distintos investigadores quienes han observado el problema de la edad más como una construcción social y cultural. ${ }^{8}$

El segundo de ellos corresponde al artículo "La evolución de la infancia” (1974) de Lloyd DeMause quien afirma que la historia de la infancia "es una pesadilla de la que hemos empezado a despertar recientemente", y en cuanto más tiempo se retrocede, "más bajo es el nivel de puericultura y más expuestos están los niños a la muerte violenta, al abandono, los golpes, el terror y los abusos sexuales".? Su trabajo que lo orienta por la teoría psicogénica expone, entre otras cuestiones, la experiencia sexual adquirida por los infantes y trasmitida por los adultos desde la Antigüedad, sin faltar desde el tocamiento y los juegos sexuales, la masturbación, la violación y hasta la castración, todo ello visto como algo natural. Con el surgimiento del cristianismo se impuso el debate sobre la inocencia del niño, pero las prácticas sexuales de toda la Edad Media y del Renacimiento continuaron involucrando a éste como objeto sexual. A

${ }^{7}$ Philippe Ariés, El niño y la vida familiar en el Antiguo Régimen, passim capítulo I. Las edades de la vida, México, Taurus, 1998.

${ }^{8}$ Vid Alberto del Castillo Troncoso, Conceptos, imágenes y representaciones de la niñez en la ciudad de México, 1880-1920, México, El Colegio de México, Instituto Mora, passim "La invención de un concepto moderno de infancia".

${ }^{9}$ Lloyd DeMause, "La evolución de la infancia" en Historia de la infancia (1974), Madrid, Alianza Editorial, 1982, 15. 
pesar de los afanes moralistas por evitar el uso sexual de los infantes, éste se incrementó, aunque en el siglo XviII se dio un cambio importante cuando se normó el castigo contra nińos y nińas que se masturbaban.

El exponer algunas de las principales ideas de dos de los pioneros de la historia de la infancia como lo han sido Ariés y DeMause, ${ }^{10}$ tuvo como propósito conocer teorías diferentes, en la que una de ellas, la de DeMause, hace referencia a la violencia sexual que recibían los niños en su época de estudio, misma que para Ariés pasó desapercibida.

En lo que respecta a la historia de la juventud como otra etapa en las "edades del hombre", ha representado también un problema importante como así se explica en la Historia de los jóvenes que coordinaron G. Levi y J.C. Schmitt, quienes afirman en la "Introducción" que ésta "implica, por consiguiente, una pluralidad de perspectiva: en la medida en que es el término de una fase de socialización previa a la edad adulta"; que se significa por el momento "liminar" de los ritos de paso, tanto de salida de una etapa (la infancia y la adolescencia) a la entrada de la nueva y que tienen que ver con la "formación y transformación de cada ser, de la maduración del cuerpo y la mente". Para ellos, el reto para el historiador que se preocupa por la juventud "es rastrear la pista del sentimiento de identidad individual y colectiva, y la del apego de solidaridades que llevan a que los jóvenes pasen a ser un grupo social ritualmente organizado, o políticamente activo en determinado momento de la historia". ${ }^{11}$

Por otro lado, la violencia sexual contra niños y jóvenes ha sido reiterativa desde hace siglos, y a ella se han abocado algunos estudios como el de Joanna Bourke en Los violadores. Historia del estupro de 1860 a nuestros días en el que expone el fenómeno de la violación y el estupro con un carácter cultural, es decir, contrario a que este tipo

${ }^{10}$ Otro de los trabajos clásico sobre el tema es: Historia de la infancia del español Buenaventura Delgado (véase bibliografía) quien en su investigación se centra principalmente en aspectos pedagógicos, aunque no ignora a la infancia marginada ni la violencia ejercida históricamente contra ésta.

${ }^{11}$ Giovanni Levi y Jean-Claude Schmidt, op. cit., pp. 13-14. 
de violencia sexual sea de carácter natural como lo llegara a tratar de demostrar Randy Thornhill y Craig T. Palmer. ${ }^{12}$

Bourke no sólo afirma que no todos los hombres son violadores, sino que explica que este fenómeno responde a entornos políticos, sociales y económicos singulares, y caracteriza la violación como violencia sexual y "una de las formas fundamentales en las que opera el poder dentro de nuestra sociedad", y la observa como un problema que permea todos los niveles sociales y de la misma ley. ${ }^{13} \mathrm{Al}$ develar algunos de los mitos en torno a la violación, reconoce a éstos como "estrategias mediante las cuales se podía marginar aún más a los miembros menos poderosos de una comunidad [...] permiten a los que cometen abusos justificar el dolor que causan". ${ }^{14}$ Así mismo, se interesó en buscar y encontrar respuestas a la violación en los factores ambientales con lo que logró, a través de los estudios de diversas feministas, romper con los viejos estereotipos que situaban al violador en los márgenes de la sociedad, "sacándolo del duro mundo de las calles y situándolo en entornos blancos de clase media, aparentemente plácidos", ${ }^{15}$ en los que no faltan el hogar, el ejército o la prisión. Observa en la desmitificación del violador que la violencia sexual ya no parezca inevitable. Concluye señalando que la acción de universalizar la violación ( $v g r$. "todos los hombres son violadores"),

${ }^{12}$ Randy Thornhill y Craig T. Palmer en su obra Una historia natural de la violación, afirman que la violación representa un hecho biológico. Sus argumentos, apoyados en la biología evolutiva, intentan demostrar que la violación "surgió como una respuesta al surgimiento de los mecanismos psicológicos que regulan la conducta femenina, los cuales permitieron a las mujeres discriminar entre compañeros sexuales potenciales". Para ellos, la violación se pudiera haber evitado si la selección entre hombres y mujeres hubiese sido de manera distinta a lo que ésta fue, por ejemplo, que la mujer seleccionase indiscriminadamente a su pareja o, bien, que los hombres desearan tener contacto sexual sólo con mujeres que tuvieran disposición a copular con éstos. Pero como la selección no favoreció este tipo de adaptaciones, "las causas próximas de la violación en el ser humano radican en las adaptaciones diferenciales de la sexualidad masculina y la femenina". Randy Tornhill y Craig T. Palmer, Una historia natural de la violación. Los fundamentos biológicos de la coerción sexual, México, Editorial Océano, 2006, 128-129, 178.

${ }^{13}$ Joanna Bourke, Los violadores. Historia del estupro de 1860 a nuestros dias, Barcelona, Crítica, 2009, 501.

${ }^{14}$ Ibidem, p. 64.

${ }^{15}$ Ibidem, p. 180. 
supone suprimir los detalles de las historias individuales y las posibilidades de actuar de otra manera. Supone situar la tortura sexual en el ámbito de la edificación moral. El sujeto traumatizador (el violador) es un ser consciente que tiene ante sí una diversidad de conocimientos, emociones deseos y necesidades. Poniendo al descubierto sus múltiples voces, hacemos accesibles a la imaginación y refutable en un plano político. Revelando las especificidades del pasado, podemos imaginar un futuro en el que la violencia sexual haya quedado fuera del umbral de lo humano.

Orientado principalmente por las ideas de Joanna Bourke sobre violencia sexual, este trabajo comprende la cultura por su gran diversidad y flexibilidad, misma en la que la propia sexualidad presenta complejas y ricas variantes entre los grupos humanos en el que la violación y otros delitos análogos, no quedan fuera de la misma al ser parte de la violencia que permea distintos ámbitos, instituciones, normas y grupos humanos en sus muy singulares contextos.

\section{CUERPO, MORAL SEXUAL Y LEGISLACIÓN}

Terminada la Colonia, el cuerpo representó el foco en el que se centró la atención moralista de la familia burguesa y de la sociedad en general, y por el cual se formalizaron saberes y se montó un aparato de vigilancia que escudrińaba los rincones más privados. En él, la incontinencia entrañaba en sí los peligros de la libertad del cuerpo expresada en las necesidades sexuales. Si el pudor y la vergüenza surgieron como recursos para frenar ciertos comportamientos, la continencia se presentó como el medio para controlar estos deseos naturales y "la preocupación de evitar cualquier manifestación orgánica capaz de recordar que el cuerpo existe". ${ }^{16}$

El silencio sobre el sexo y la sexualidad en el interior de la familia adquirió, en general, un significado particular que tuvo por objeto defender el carácter procreativo de las relaciones sexuales conyuga-

${ }^{16}$ Alain Corbín, "Entre bastidores" en Historia de la vida privada. Sociedad burguesa: aspectos concretos de la vida privada, t. 8, dirigida por Phillippe Ariès y Georges Duby, Madrid, Ed. Taurus, 1991, 152. 
les frentes a las prácticas "ilegítimas" que tenían por objeto el placer y el erotismo y en el que el silencio no sólo era innombrable, ${ }^{17}$ sino necesario e inevitable en la defensa de una moral sexual conservadora. Dentro de esta cruzada moral, la vigilancia de los hombres y mujeres, sobre todo en los más jóvenes, se centró en evitar las prácticas sexuales solitarias y prácticas como la prostitución, lo cual debía ser útil para controlar las pulsiones y tentaciones que ofrecía la carne.

Sin embargo, este discurso moral no alertaba de otros peligros reales que podían presentarse, incluso dentro de la propia familia, como lo fue la violencia sexual, entendida ésta como el acceso carnal ilegítimo realizado principalmente contra mujeres y niños, y que se hizo aún más comprensible bajo los conceptos jurídicos de violación y estupro.

\section{Legislación y género}

Lograda la independencia, la legislación se caracterizó por su enorme dispersión en la que convivían leyes penales mexicanas y aquéllas de origen colonial, incluidas aquellas que castigaban los delitos sexuales. ${ }^{18}$ Para resolver este problema fue necesario promulgar los primeros códigos, entre ellos el civil y el penal. La divulgación de diversos códigos y reglamentos de carácter liberal como el famoso código civil que causó tantas controversias y pugnas entre liberales y conservadores y entre la Iglesia católica y el Estado. Este código civil instaurado en México en 1871, y en Jalisco en 1875, daba a la mujer casada prácticamente un trato de infante, al hacerla dependiente de la figura masculina, ya que el marido era el representante legal de ella y

${ }^{17}$ Carlos Monsiváis, "Prólogo" en Ava Vargas (colección de fotografías), La casa de citas en el barrio galante, México, Grijalbo y Conaculta, 1991, IX.

${ }^{18}$ Elisa Speckman explica que en el México independiente del siglo xIX se mantuvieron en vigor, junto con las constituciones políticas de la nueva nación y de la nuevas leyes penales mexicanas, diversos "cuerpos y obras jurídicas hispánicas" entre las que se encontraban la Novísima recopilación, además de ser muy frecuente la consulta de las Siete partidas, entre otras. Elisa Speckman Guerra, Crimen y castigo. Legislación penal, interpretaciones de la criminalidad y administración de la justicia (Ciudad de México, 1872-1910), México, El Colegio de México y unam, 2002, 23. 
aunque la mujer conservaba el derecho para defenderse de cualquier juicio criminal, su derecho de ser realmente escuchada se demeritaba frente a los argumentos masculinos, pues la ley marcaba privilegios que favorecían claramente al hombre.

Desde el momento en que el citado código refería que la mujer mayor de 21 ańos, pero menor de 30 no podía abandonar la casa "paterna" sin licencia del padre o de la madre, a menos de que fuera para casarse o cuando aquéllos se divorciasen, ${ }^{19}$ se puede entender que a la mujer realmente no se le reconocía de hecho el ser "mayor de edad", aunque el código civil mencionase lo contrario, ya que la dependencia masculina iniciada en el seno familiar continuaba en su matrimonio.

El ser hombre o mujer significaba una diferencia de poderes que surgía inicialmente de la dicotomía originada por una supuesta diferencia corporal: la fuerza y la debilidad; la dureza y la fortaleza masculina frente a la "eterna" debilidad femenina y, con ello, los privilegios para los unos y las desventajas para las otras; una debilidad que se internalizaba desde la familia: a la mujer se le había enseñado a aceptar y a transmitir la autoridad masculina, por lo tanto, debía renunciar consciente o inconscientemente a criticar, examinar y juzgar por su cuenta. ${ }^{20}$

El grado ideal de la mujer en el discurso del sistema patriarcal $^{21}$ del siglo xIx era el que se alcanzaba por medio de la docilidad y la

${ }^{19}$ Código Civil del Estado de Jalisco (1870), Guadalajara, Tipografía de S. Banda, 13 de diciembre de 1875, 147.

${ }^{20}$ Vid Verena Radkau, Por la debilidad de nuestro ser. Mujeres del pueblo en la paz porfiriana, México, Cuaderno de la Casa Chata, Ciesas, 1989.

${ }^{21}$ El concepto del "sistema patriarcal" o de "patriarcado" ha sido sumamente debatido a partir de los sesenta del siglo pasado. Una de las definiciones que mejor se ajusta a este ensayo es la de Gerda Lerner quien lo explica como "la manifestación e institucionalización del dominio masculino sobre mujeres y niños (as) en la familia y la extensión del dominio masculino sobre las mujeres a la sociedad en general. Implica que los hombres ostentan el poder en todas las instituciones importantes de la sociedad y que las mujeres son privadas de acceso a ese poder. Lo anterior no significa que las mujeres carezcan totalmente de poder ni que estén totalmente privadas de derechos, influencias y recursos". Gerda Lerner. "The creation of patriarchy", citado en María Milagros Rivera Garretas, en Nombrar el mundo en femenino. Pensamiento de las mujeres y teoría feminista, España, Icaria Editorial, 1994, 72. 
sumisión, atributos construidos histórica y culturalmente y que han implicado el cumplimiento de un rol de género tradicional que durante el porfiriato fue enfatizado hasta sus extremos.

En este plano jurídico, las relaciones de poder entre hombres y mujeres mantienen una desigualdad de género ${ }^{22}$ a favor de los primeros y cuyo resultado sostiene y justifica una permanente violencia simbólica, aunque la violencia física siempre se mantiene latente y se reproduce cuando los límites del habitus son rotos o ignorados. ${ }^{23}$

El diccionario Escriche, publicado en España el año 1873 y de gran consulta en los tribunales y juzgados de México y Jalisco, definía la incontinencia como "el abuso de los placeres sensuales y toda clase de unión ilegítima entre personas de diverso sexo" y refería que estos tipos de delitos eran: el amancebamiento o concubinato, la bigamia o poligamia, el estupro, el incesto, el lenocinio, el rapto, la sodomía o pederastia y la bestialidad.

El código penal mexicano, decretado en 1875 y en el caso de Jalisco, hasta agosto de 1885 . En este código se incluyeron ciertos delitos de incontinencia bajo el nombre de "delitos que atentaban contra el orden de la familia, la moral pública ó las buenas costumbres" (atentados contra el pudor, estupro, violación, corrupción de menores, rapto, adulterio, bigamia, ultrajes a la moral pública o a las buenas costumbres) y no se tipificaba el incesto, aunque sí se incluía

${ }^{22}$ Carmen Ramos Escandón ha reconsiderado la definición que Joan Scott hizo de la categoría de "género" ( "la organización social de las relaciones entre los sexos") y la comprende en el marco de la temporalidad y el espacio, y "no en una relación condicionada y predeterminada por la biología”. Así también confirma que para explicar objetivamente la opresión de las mujeres en el sistema patriarcal es necesario tomar en cuenta el factor histórico. Carmen Ramos Escandón, "La nueva historia, el feminismo y la mujer" en Carmen Ramos Escandón, comp., Género e historia. La historiografia sobre la mujer", México, Instituto Mora y Universidad Autónoma Metropolitana, 1997, 13-14 y 15-17.

${ }^{23}$ Para Pierre Bourdieu la violencia simbólica es la impuesta a través de una dominación masculina que la explica como una "violencia amortiguada, insensible, e invisible para sus propias víctimas, que se ejerce esencialmente a través de los caminos puramente simbólicos de la comunicación y el conocimiento o, más exactamente, del desconocimiento, el reconocimiento o, en último término, del sentimiento". Dominación qué, como lo explica el mismo Bourdieu, "se afirma en la objetividad de las estructuras sociales y de las actividades productivas y reproductivas, y se basa en una división sexual del trabajo de producción y de reproducción biológico y social”. Pierre Bourdieu, La dominación masculina, Barcelona, Editorial Anagrama, 1999, 12, 49. 
dentro del de "violación", el cual se castigaba hasta con seis años de prisión y se incrementaba dos más cuando el reo era ascendiente, descendiente, padrastro o madrasta del ofendido o a sólo un año más si el reo era hermano de éste.

En el caso del estupro este mismo código lo define como la "cópula con mujer casta y honesta, empleando la seducción o el engaño para alcanzar su consentimiento, mientras que al delito de violación como el "que por medio de la violencia física o moral, tiene cópula con una persona sin la voluntad de ésta, sea cual fuere su sexo" 24 es decir, la diferencia estribaba en la castidad o virginidad de la mujer, en el empleo de la violencia y en el hecho de que la violación podía afectar tanto a la mujer como al varón.

$\mathrm{Al}$ delito de rapto, el código penal de Jalisco lo definió como "el que contra la voluntad de una mujer se apodere de ella y se la lleve por medio de la violencia física o moral, del engaño o seducción, para satisfacer algún deseo torpe o para casarse" ${ }^{25}$ La pena para el raptor era de cuatro hasta doce años de prisión conforme a los agravantes, aunque si éste se casaba con la agraviada el proceso criminal se suspendía. ${ }^{26}$

Dichos fenómenos tuvieron por contexto una cultura de la violencia en un momento en el que el propio Estado intentó mejorar su legislación penal, reorganizar la administración de la justicia y construir un nuevo tipo de ciudadano más conforme con las nuevas ideas de orden, modernización y progreso.

\section{Honor e incontinencia sexual}

El concepto de honor se puede definir como una virtud para la defensa de la honestidad, laboriosidad, valentía, potencial sexual, etcétera, y como un bien o un capital intangible, de carácter personal, familiar o de grupo que busca el respeto y la consideración social y que se ejemplifica por el calificativo de la "pública buena fama”. La

${ }^{24}$ Código Penal del Estado de Jalisco (1885), Guadalajara, Tipografía de la Escuela de Artes y Oficios, 1907, 173-174.

${ }^{25}$ Ibidem, p. 176.

${ }^{26}$ Ibidem, pp. 176-177. 
parte antagónica del honor es el deshonor producto de la "mala fama”, y que produce la vergüenza y el estigma de los afectados. ${ }^{27}$

El honor de la familia burguesa en el siglo XIX fue algo que no se podía poner en tela de juicio por ningún motivo. La preservación del honor familiar estaba unida intrínsecamente al interés por mantener la "buena fama". ${ }^{28}$ La familia, como lo señala Michelle Perrot era en buena parte "un capital simbólico del honor" 29 y como tal había que cuidarlo. El deshonor, producto del escándalo era una mancha que no sólo contaminaba al infractor, sino que extendía su influjo negativo al resto de la familia.

En un sistema patriarcal de carácter tradicional, el rol sexual y social de la mujer desde el discurso masculino, estaba centrado en el matrimonio como su principal referencia y vinculado por "obviedad" al hogar en donde la mujer tenía su supuesta pertenencia e identidad. La pureza de una mujer hasta su matrimonio no era tan sólo una virtud que se confería a ella misma, sino que se transfería al dominio e interés de su familia y en particular al jefe de la misma, quien se convertía en el principal defensor del honor familiar. $\mathrm{Al}$ ser quebrantada la virginidad de la mujer fuera de matrimonio o al tener una conducta escandalosa y después de hacerse notoria o pública, la "mala fama" invadía además al cuerpo familiar.

Aunque los moralistas porfirianos no concebían que la mujer fuera la única que incitara a la lujuria, sí la consideraban el "centro y eje alrededor del cual gravita[ba]n y gira[ba]n casi todas las manifestaciones [o excitaciones] de la vida social". ${ }^{30}$ Manifestaciones que se podían

${ }^{27}$ El antropólogo Julian Pitt-Rivers explica el honor como "el valor de una persona para sí misma, pero también para la sociedad” y lo asocia a la conducta, al orgullo, a la reputación, a la identidad, a la vergüenza, a la vindicación, a una posición social, que se ritualiza a través del cumplimiento de los códigos de honor. Julian Pitt-Rivers. Antropología del honor o políticas de los sexos, España, Grupo Editorial Grijalbo, 1979, passim pp. 18-40.

${ }^{28} \mathrm{La}$ buena fama corresponde a la consideración que tenía la opinión pública acerca de los hombres y mujeres que vivían rectamente conforme a la ley y a las buenas costumbres y por lo tanto lo contrario ocurría con la "pública mala fama". Joaquín Escriche y Martín, Diccionario razonado de Legislación y Jurisprudencia (Madrid, 1873), vol. 1, México, Cárdenas Escritor y Editor, 1991, 673.

${ }^{29}$ Michelle Perrot, "Dramas y conflictos familiares" en Historia de la vida privada, vol. 7, op. cit., p. 272.

${ }^{30}$ BPEJ. SFE (Biblioteca Pública del Estado de Jalisco. Sección de Fondos Especiales). 
cargar, desde un principio moralizante a una atmósfera de supuesta voluptuosidad, en el que el matrimonio estaba al decir de los moralistas "menos expuesto a las consecuencias degenerantes de la lujuria". ${ }^{31}$

Contraria a la mujer, la conducta escandalosa del hombre no era un asunto que preocupara en demasía a la sociedad, él podía desarrollar las más "intensas pasiones" y tener vicios como el alcohol y el juego, sin que llegara a desprestigiarse del todo; una "aventurilla" amorosa significaba para el hombre el mantenimiento de su honorabilidad y el reconocimiento de su fama de conquistador. ${ }^{32}$

\section{ViOLACión}

Para el médico-legista porfiriano Francisco A. Flores, ${ }^{33}$ el contingente que ofrecía el delito de violación (y estupro) a la criminalidad se incrementaba anualmente, aunque observó que su cifra no era real debido a que la legislación penal no perseguía de oficio tales delitos, sino por petición de las partes afectadas, y aún persiguiéndolos de oficio hubieran sido, a su juicio, muy pocos los casos que el Ministerio Público conocería de ellos, las razones de este ocultamiento se debían "porque los ofendidos ignoren la desgracia de sus familias, ora porque, aun sabiéndola, prefieran, como dice muy bien [Pedro] Mata [Fontanet], 'devorar en silencio este ultraje y hacer que no cunda más sobre el terso cristal de la honra de la desflorada la mancha que les ha dejado el estuprador' " ${ }^{34}$

Para ejemplificar el problema de los delitos sexuales cometidos contra mujeres en Jalisco en el periodo estudiado, una pequeña

Miguel Galindo, Apuntes sobre la higiene en Guadalajara, Tesis de recepción presentada ante la Fac. de Medicina de Guadalajara. Guadalajara, 1908, p. 266, Miscelánea 492.

${ }^{31}$ Idem.

${ }^{32}$ Jorge Alberto Trujillo Bretón, "Miguel Galindo y la Ciudad del Polvo” en Revista del Seminario de Historia Mexicana, Guadalajara, Universidad de Guadalajara y Benemérita Universidad Autónoma de Puebla, época 1, vol. 1, núm. 2, invierno de 1997, 96-99.

${ }^{33}$ Para una interpretación del ensayo El himen en México de Francisco A. Flores, publicado en 1885, y que se refiere a continuación, véanse los ensayos de Frida Gorbach y Miruna Achim que se encuentran en esta misma obra.

${ }^{34}$ Francisco A. Flores, El himen en México (1885), Con/textos de Historia de la ciencia, México, Conacyt, Instituto de Investigaciones Filosóficas-unAM, 2006, 15. 
muestra nos puede ser de utilidad. De un total de 58 expedientes revisados se encontraron cinco tipos de delitos principales: estupro, incesto, violación, rapto y adulterio, de los cuales 21 se realizaron en Guadalajara y los restantes 37 en otras localidades del estado. ${ }^{35}$ Cabe mencionar que el médico higienista Miguel Galindo observó para Guadalajara las siguientes cifras: ${ }^{36}$

\begin{tabular}{ccc}
\hline Bienios & Estupro & Violación \\
\hline 1892 a 1894 & 81 & 15 \\
1894 a 1896 & 20 & 11 \\
1902 a 1904 & 66 & 39 \\
1904 a 1906 & 31 & 35 \\
\hline
\end{tabular}

Galindo agregó de manera separada el delito de rapto al que consideraba como congénere de la violación y el estupro y observó que en el bienio 1892 a 1894 se presentaron 55 acusaciones por rapto, y en el cuatrienio de 1902 a 1906 hubo $101 .^{37}$

Las víctimas femeninas en nuestra muestra sumaron un total de 59 y de ellas 29 contaban con una edad que oscilaba entre los 11 y 15 ańos (49\%), y 36 (61\%) fueron víctimas de estupro, aunque no faltaron en número mucho menor delitos como violación, incesto, rapto, lenocinio y adulterio. En su gran mayoría la edad de aquellos que abusaron de estas jóvenes mujeres era entre los 15 y 30 años.

Si bien es cierto que en la mayoría de los delitos sexuales los novios de las víctimas eran los principales implicados (10 de un total de 22) no faltaban aquellos, un total de ocho, que por su proximidad familiar o sus lazos consanguíneos o legales (padre, padrastro y pri-

${ }^{35}$ Casi siempre estos delitos se realizaban asociados con otros como: rapto y estupro, rapto, estupro e incesto, allanamiento de morada y rapto, estupro y lenocinio, violación e infanticidio. Vid Código Penal de Jalisco (1885), Guadalajara, Jal., Tip. de la Escuela de Artes y Oficios del Estado, 1907.

${ }^{36}$ Miguel Galindo, Higiene socialy medicina legal, tesis de recepción (vol. 2), Guadalajara, 1908, 187.

${ }^{37}$ Ibidem, p. 189. 
mos, en ese orden) realizaran tales abusos, lo cual nos habla de la peligrosidad que podía representar la familia para las mujeres jóvenes.

\section{Maria y los actos "inicuos" de su padre desalmado}

Conforme al citado Miguel Galindo, el estupro y la violación tenían su principal fuente en las mujeres del pueblo, ya que según él éstas presentaban una facilidad relativa y cuya poca resistencia exaltaba el deseo de su agresor. Galindo señala que la violación era realizada por sátiros perversos generalmente de corta edad y quienes llegaban a emplear algunas veces la violencia física. Entre los casos que le tocó observar fue el de un padre quien pretendió violar a sus dos hijas, "una de las cuales, la única que se presentó al examen médico-legal, tenía apenas la edad de ocho a diez años. Por fortuna estos casos de violación complicada con incesto no son muy frecuentes" ${ }^{38}$

El incesto, ${ }^{39} \mathrm{o}$ sea el establecimiento de relaciones sexuales entre individuos efectuado por consanguinidad o parentesco es un fenómeno que por lo general ha sido prohibido. ${ }^{40}$ En la Nueva España la

${ }^{38}$ Miguel Galindo, Higiene social y medicina legal, op. cit., p. 184.

${ }^{39}$ Desde hace mucho tiempo el incesto ha sido del interés de investigadores de diversas disciplinas científicas, principalmente antropólogos y psicoanalistas, entre los que han destacado: James Frazer, Sigmund Freud, Bronislaw Malinowki, Claude Levi-Strauss, sólo por citar a los clásicos. Por cuestión de espacio es importante mencionar al menos el libro Tótem y tabú de Sigmund Freud quien explica este fenómeno por haber provocado el nacimiento de la exogamia y con ello la prohibición de la relación sexual entre miembros de un mismo clan, misma que la consideró la base de la comunicación y la cultura. Antes de esta prohibición los patriarcas del clan acaparaban a las hembras, lo cual llevó a los miembros más jóvenes del mismo grupo a asesinar y a devorar a su padre (el tótem). Tal homicidio, de carácter edípico, provocó la culpa de quienes lo realizaron y con ello se estableció el tabú del incesto y el homicidio. Vid Sigmund Freud, Tótem y tabú, Madrid, Alianza, 1999.

${ }^{40}$ Según Robin Fox el incesto llegó a ser permitido en algunas antiguas culturas desde tiempos inmemoriales, vgr. Irán y Egipto. Esta costumbre fue generalmente, y no universalmente, prohibida a través del establecimiento de la exogamia, y más tarde penada por la sociedad industrial, y agrega que al estar el incesto relacionado con el sexo, la exogamia lo ha estado con el matrimonio. Fox, rescata de Lévi-Strauss, que el tabú del incesto puede ser considerado como la regla de reglas, y representa "el salto por encima del abismo entre el hombre y el animal". Actualmente dicha costumbre se observa todavía en algunos grupos humanos. Robin Fox, La roja lámpara del incesto, México, Fondo de Cultura Económica, 1990, passim "I. Se enciende la lámpara”. 
legislación colonial espańola consideraba al incesto más que un crimen una herejía, y se cometía cuando un hombre o una mujer mantenían relación sexual con algún pariente de hasta cuarto grado, con su comadre o compadre, con el cuñado o cuñada, con una mujer u hombre religiosos. ${ }^{41}$ En las postrimerías del siglo XIX, Jalisco no contaba expresamente con una ley que prohibiera el incesto, sin embargo, sí se hacía dentro de los delitos de violación y estupro con penas que iban de dos hasta diez años de prisión dependiendo de las circunstancias. ${ }^{42}$ Es también claro que el peso de las costumbres, la moral, la religión y la educación han formado un muro para que los comportamientos sexuales considerados anormales o desviados sean reprimidos y controlados.

Un buen ejemplo sobre incesto ocurrido en Jalisco durante el porfiriato lo representa el efectuado en 1885, cuando Isidoro González, indígena de 56 años de edad, viudo, de ocupación jornalero, vecino de Mochiltic, ${ }^{43}$ una hacienda del municipio de Hostipaquillo, Jalisco, fue detenido y procesado penalmente por lo delitos de estupro con violencia, incesto en primer grado en línea recta con circunstancias agravantes ${ }^{44} \mathrm{y}$ por conatos de asesinato, en la persona de María González, de 18 años, soltera e hija legítima del agresor. Al hacer la denuncia María expresó que antes de ser estuprada había huido de su padre porque ya la había amagado anteriormente, sin lograr su propósito y que desgraciadamente él se percató en donde se encontraba (en Talpa con una familia conocida) y la mandó traer de vuelta. Al recibirla la golpeó como a "un animal bruto" y la forzó sexualmente con puñal en mano. Al reclamarle su padre que se hu-

${ }^{41}$ Carlos V (formador), Novisima recopilación de las leyes de España recopilada y publicada por Felipe II en el año de 1567 y reimpresa en el de 1775 y en el que se incorporaron las pragmáticas cédulas, decretos, órdenes y resoluciones reales y otras providencias recopiladas y expedidas hasta el año de 1804, t. v, libro XII, título XXIX. Madrid, 1805, 426.

${ }^{42}$ вреJ. Código Penal de Jalisco (1885), Guadalajara, Jal., Tipográfica de la Escuela de Artes y Oficios del Estado, 1907, 174.

${ }^{43}$ En 1888, la hacienda de Mochiltic formaba parte del municipio de Hostotipaquillo (12 ${ }^{\circ}$ Cantón del estado). Mariano Bárcena, Ensayo estadístico de Jalisco, México, Gobierno de Jalisco, 1983.

${ }^{44}$ BPEJ. SFE. AHSTJJ (Archivo histórico del Supremo Tribunal de Justicia de Jalisco), caja sin número, 1886, exp. 800 . 
biera ido sin su permiso, la amenazó diciéndole "que todos los días que le quedaran de vida a uno y a otro, había de ser su concubina, porque de que la gozara otro, a derecho estaba él que la había engendrado y criado a la vez".

Al hacer su declaración Isidoro González definió al estupro como una "circunstancia que jamás podrá negar, porque es del todo cierto" y lo calificó de un hecho "inicuo". González fue condenado a purgar una pena de seis años de prisión con la correspondiente pérdida de la patria potestad de su hija. En este caso fue el propio progenitor quien convirtió a su hija en un objeto sexuado de su posesión y él, por su comportamiento desviado, quedó etiquetado como un trasgresor de la moral sexual socialmente aceptada. Robin Fox explica, retomando a Claude Lévi-Straus y a George P. Murdock, que, al trastocar las relaciones de intercambio, al hombre incestuoso "se le compara con un avaro, o con alguien que sólo habla consigo mismo: lo que niega son las posibilidades de cualquier tipo de relación social", 45

Por ello tal caso no sólo se presenta como un rompimiento brutal del tabú sexual y de los preceptos religiosos y legales, con la característica especial de haberse realizado en un medio rural, semiaislado ${ }^{46}$ y que debió servir para que las pulsiones sexuales pudieran presentar una menor inhibición, sino que además el padre por su comportamiento sexual desviado atentara contra los intereses de su propia comunidad, especialmente en el número de mujeres potencialmente casaderas de la hacienda, es decir, disminuyendo la oferta de mujeres en edad para contraer matrimonio. Con ese tipo de comportamiento sexual no sólo se atentó contra las costumbres y la moral social de fines de siglo XIx, sino también se hizo contra la propia institución del matrimonio tanto religioso como civil.

${ }^{45}$ Robin Fox, op. cit., p. 26.

${ }^{46}$ Para Esteban Barragán y Thierry Linck lo singular de las zonas rurales mexicanas (y entre ellas la jalisciense) son y han sido: su aislamiento, marginalización, baja densidad y alta dispersión de población. Esteban Barragán y Thierry Linck, "Los rincones rancheros de México" en Rancheros y sociedades rancheras, Zamora, CEMCA, El Colegio de Michoacán y ORSTOM, 1994, 67-68. 
El futuro de la mujer agredida por su propio padre era el más incierto de todo tipo de violencia sexual pues difícilmente podía recurrir a un matrimonio, aún desventajoso, al perder la protección paterna y al ser estigmatizada por los habitantes de esa población.

\section{Las Memorias del Diablo}

En ocasiones el deseo de una sexualidad expresada dentro del matrimonio era alterado con la realización de delitos sexuales que podían llegar a enfrentar a sus víctimas con embarazos no deseados, aunque cabe mencionar que la relación sexual anticipada al matrimonio también ofrecía a la mujer la posibilidad de escapar del yugo familiar y hacer vida en pareja con su presunto "violador". El siguiente caso ilustra el estupro sufrido por una muchacha obrera de Guadalajara.

El día 19 de abril de 1899, se presentó en la Comisaría Municipal de Guadalajara la señora Juana Hernández, de 31 años de edad, casada, de ocupación planchadora para declarar que su sobrina Bernarda Pérez había tomado algunas copas de licor en el interior del tendajón Las Memorias del Diablo y que al quedarse dormida bajo el mostrador debido la ebriedad en que se encontraba, ${ }^{47}$ había sido violada por el propietario y dependiente de ese negocio. Ratificó que su sobrina era doncella, huérfana de madre y de buena reputación, contaba con una edad de doce a trece años de edad cuando ocurrieron los hechos. ${ }^{48}$ Bernarda recordó lo sucedido de la siguiente manera:

Se metió dentro del mostrador y se acostó para ver si se le cortaba la borrachera, pero José Martínez de Robles abusando del estado en que se encontraba, hizo uso de su persona deshonrándola, pues antes gozaba del estado

${ }^{47}$ Elisa Speckman señala para el caso de México que "era habitual y al parecer aceptado que la mujer acudiera a las pulquerías". Seguramente en Jalisco era también normal y probablemente aceptado que la mujer del pueblo acudiera a beber sobre todo en tendajones, aunque el discurso porfiriano y las principales instituciones no estuvieran de acuerdo con dicho comportamiento. Elisa Speckman, "Las flores del mal. Mujeres criminales en el porfiriato" en revista Historia Mexicana, núm. Xvir, México, Colegio de México, 1997, 211.

${ }^{48}$ BPEJ. SFE. AHSTJJ, caja 3253, 1899, exp. 105. 
de doncella [...] Que no pudo resistir a la violencia [...] por el estado de ebriedad en que se encontraba y cuando volvió en sí sólo notó que Martínez la tenía tomada de un pecho. Que notó que estaba deshonrada porque se vio sucia de todas sus ropas interiores. ${ }^{49}$

El presunto estuprador, de nombre José Martínez de Robles, de 20 años de edad y quien se declaró comerciante y zapatero y originario de Guadalajara, negó que hubiese abusado de Bernarda y sí que la había tocado, encargándose además de difamarla. Después de un proceso irregular (el juez de lo criminal nunca ordenó la realización de un examen corporal como era obligatorio por ley), ordenó la libertad de Martínez exculpándolo de ese cargo.

Tales casos como el de Bernarda nos inducen a pensar, que independientemente de que algunas de estas muchachas hayan tenido relaciones sexuales voluntarias (y no una violación) con sus novios o sus seductores, bajo promesa de matrimonio y que éste se haya cumplido, otras simplemente no lo lograron, lo que les podía implicar que al quedar embarazadas y fuera de matrimonio, obtuvieran el repudio familiar y socialmente una "pública mala fama", además de que su hijo fuese nombrado con el adjetivo de "bastardo" lo que le privaría de los derechos que normalmente le corresponderían si hubiese sido un hijo legítimo (por ejemplo la herencia de su padre).

En el caso de las mujeres violadas que no contrajeron matrimonio, su situación se tornaba más complicada pues podía llevarlas a una catástrofe que probablemente les llevaba a perder la protección paterna, no sin antes haber corrido los riesgos propios del enojo de sus padres y se vieran de pronto arrojadas a la calle y estigmatizadas como "mujeres fáciles" o de "malas costumbres".

La pérdida de esa protección las podía dejar indefensas frente a otros actos de violencia y tal como lo señala Steve J. Stern para la Colonia mexicana, "se justificaba una respuesta masculina y violenta y la impunidad con la que se acogía tal respuesta" ${ }^{50}$ Dicha pérdi-

${ }^{49}$ Idem.

50 Steve J. Stern, La historia secreta del género, México, Fondo de Cultura Económica, $1999,75$. 
da también llegaba a conducir a la mujer hacia una independencia sexual que la libraba en buena parte del rol tradicional femenino, pero que no escapaba del todo del ejercicio de la violencia masculina que siempre se mantenía latente. Otra consecuencia de esta experiencia podía llevarla a ser incorporada al mundo de la prostitución. ${ }^{51}$

Como se puede observar, tal como lo explica Georges Vigarello, para el caso de Francia en el siglo xIx, este tipo de violencia va dirigida sobre todo contra las más jóvenes por ser las "víctimas designadas por su escasa fuerza más que por su cuerpo nubil”. Para Vigarello la víctima infantil es un sustituto habitual para una sexualidad oprimida, y explica: "La agresión tradicional más zafia predomina en estos hechos contra menores: impulso rudimentario más que deseo 'vicioso', sexualidad pobre más que sexualidad licenciosa; acto de dominio, sobre todo, impuestos a los más débiles según la lógica secular de una sexualidad de poder y opresión". ${ }^{2}$

\section{Lenocinio y venta de virginidades}

Dentro del mercado del vicio no faltaban casos de niñas y adolescentes que eran prostituidas por sus mismos familiares o por personas cercanas a éstas. En este caso eran nińas-mujeres las que eran ofrecidas a sujetos de diversas edades y posición social ofreciéndoles la venta de la virginidad de la niña impúber a un costo que podía ser elevado. La castidad que se ponía en juego en este extremo mercado pudo significar para aquel que pagara por el himen infantil la carga erótica del desfloramiento de la víctima. Sin embargo, el placer sexual no era la única ganancia para este tipo de sexo ilegal ya que también se creía que tener relaciones con una mujer virgen pudiese eliminar las enfermedades sifilítico-venéreas, ${ }^{53}$ lo cual traía consigo

${ }^{51}$ Vid Jorge Alberto Trujillo Bretón, La prostitución en Guadalajara durante la crisis del porfiriato (1877-1911), Tesis para obtener el grado de licenciado en historia (inédita), Guadalajara, Facultad de Filosofía y Letras de la Universidad de Guadalajara, 1992, 138-139.

${ }^{52}$ Georges Vigarello, Historia de la violación, siglos XVI-XX, Madrid, Ediciones Cátedra, 1999, 252.

${ }^{53}$ Vid Georges Vigarello, op. cit., p. 119. 
crueles consecuencias para las nińas que eran iniciadas de esta forma en la vida sexual.

Uno de estos casos fue la acusación efectuada, en junio de 1895, contra Luisa Rodríguez por lenocinio y corrupción de menores en la persona de Concepción Ramírez, de quince años de edad, presentada por su madre, Bartola Trejo. Está última declaró que en el atardecer de 17 de ese mes y año, encontró a su hija en el jardín de san Francisco acompañada de una empleada doméstica llamada Aurelia y un individuo de nombre Alberto y por dicha razón los obligó a acudir a una demarcación de policía. En esta demarcación los acompañantes de su hija declararon ser novios y que nada tenían que ver con Concepción. ${ }^{54}$

Las cosas no hubiesen llegado a mayores a no ser por la declaración de Concepción quien ofreció datos alusivos al lenocinio, y que detonó un escándalo mayor:

Que al mismo tiempo declaró

allí su hija Concepción que quien tenía la culpa de su conducta era Luisa Rodríguez quien en el mes de febrero, estando Concepción al servicio de Albina Rodríguez, hermana de Luisa, la dejó encerrada en un cuarto con un individuo, ofreciéndole que después le daría no recuerda si veintitrés o treinta y tres pesos; que en la pieza en que la dejó encerrada, el individuo a que se ha referido usó de ella, y después Luisa le dijo que aquél, como era de fuera de aquí había desaparecido; que sabe que Luisa Rodríguez había vendido á una hermana suya y no sabe si habitualmente trafica con mujeres..$^{55}$

Luisa Rodríguez, una joven mujer de apenas 22 ańos, de oficio doméstica, vecina de Guadalajara y quien llegó a estar detenida por prostitución clandestina, ${ }^{56}$ declaró que había sido la madre de Concepción quien anteriormente le había propuesto que ofreciera a su hija al abogado Salvador Espańa, pidiéndole como adelanto la alta cifra de cuarenta pesos debido a que Concepción era nińa (casta).

\footnotetext{
${ }^{54}$ BPE. SFE. AHSTJJ. Juzgado 1o. de lo Criminal. 1895, exp. 146.

${ }^{55}$ Idem.

${ }^{56}$ Idem.
} 
Señaló que el licenciado España se negó a pagar tal cantidad por no tener la seguridad que la ofrecida fuese virgen. Por último, señaló que ella no la llegó a vender. El otro involucrado, Salvador Espańa, al atestiguar expuso ser soltero, mayor de edad, abogado, vecino de esta ciudad y ratificó lo declarado por Luisa Rodríguez. ${ }^{57}$ España era miembro de una conocida y respetada familia de Guadalajara y para él no hubo mayor recriminación por intentar hacer uso sexual de una menor.

El interés de Salvador España por adquirir la virginidad de la joven pone en la palestra de este tipo de violencia, a "hombres cultivados" que en su papel de acusados su rostro excluye la brutalidad que imponen, y "su palabra desafía a la lógica que los condena". ${ }^{58}$ mismos que como criminales representan "ejemplos molestos, obligando a observadores e investigadores a mezclar relatos diferentes con los demasiados sencillos de una violación cometida por un campesino primitivo o un obrero miserable" ${ }^{59}$

Después de realizados los careos entre ambas partes y de revisarse las pruebas aportadas, el juez 1o. de lo Criminal consideró que éstas no eran suficientes para probar la existencia del delito, dejándose en libertad a la inculpada el 21 de junio del mismo año.

Al parecer la venta de virginidades se encontraba algo extendida en la ciudad de Guadalajara, ya que los periódicos de fines del siglo XIX y principios del xx la llegan a referir regularmente, involucrando principalmente a las madres de las mismas niñas, y señalando como lugar propicio para tal venta los alrededores de los teatros como fue el caso del "Apolo", situado en el primer cuadro de la ciudad.

La venta de virginidades se puede presentar como el primer paso dado por tales niñas para incorporarlas de manera más plena en el mercado de prostitución que era cubierto principalmente por mujeres cuyas edades oscilaban entre los 14 y 20 años de edad. ${ }^{60}$

${ }^{57}$ Idem.

${ }^{58}$ Georges Vigarello, op. cit., pp. 252-253.

${ }^{59}$ Ibidem, p. 253.

${ }^{60}$ Vid Jorge Alberto Trujillo Bretón, La prostitución durante la crisis del porfiriato, op. cit. 


\section{DE LO PERVERSO Y LO DESVIADO}

Con el marco de las supuestas amenazas de las perversiones, vicios, e incontinencias, ${ }^{61}$ propagadas al decir del discurso moralista porfiriano, por vagos, delincuentes, prostitutas, alcohólicos, locos y "sodomitas", sumado al temor a las enfermedades sifilítico-venéreas, la sociedad construyó, a partir de un "pánico moral", ${ }^{62}$ una codificación más propia para sus deseos de "orden y progreso", amparada bajo los intereses del sistema capitalista y delineada con siglos de antelación por el deber ser del discurso religioso; un discurso moral que propalado por los grupos dominantes dirigía su interés en los niños y jóvenes, concibiéndolos como aquellos futuros adultos que se encontraban en una etapa de formación y que por tal razón tendrían con el tiempo responsabilidades mayores. Dicho interés consistía en protegerlos de cualquier tipo de contaminación que los pudiera alejar de los modelos establecidos por una moral social y familiar de carácter tradicional que veía en ellos el porvenir de la propia familia. Si la contaminación pudiese transmitirse a través de los llamados "vicios", también se corrían ciertos "riesgos" que atañían al desconocimiento del cuerpo y que por prácticas onanistas o por simple intemperancia, el futuro adulto podía, con el paso del tiempo, convertirse en un pervertido y en una lacra social que de víctima potencial de la contaminación se transformase en contaminador o, como lo señalara Michel Foucault, en uno de esos seres "anormales" a lo que la sociedad burguesa tanto temor tuvo ${ }^{63}$ y a los

${ }^{61}$ Conceptos a los que se agregó el de "degeneración”, término originado en la llamada "teoría de la degeneración", surgida en Europa occidental en el siglo XviII y que tuvo su auge a partir de la segunda mitad del xIx, que consideraba que la actividad delictiva era responsabilidad de la gente "degenerada", entre las que se incluía a homosexuales ("sexualidad contraria"), débiles mentales y locos.

${ }^{62}$ Jeffrey Weeks define el "pánico moral" como una "serie de rachas de ansiedad social que suelen centrarse en una condición o persona o grupo de personas a quienes se identifica como una amenaza a los valores y suposiciones sociales aceptados. Surgen por lo general, en situaciones de confusión y ambigüedad, en épocas en que los límites entre comportamientos legítimos e ilegítimos parecen requerir una nueva definición o clasificación”. Jeffrey Weeks, Sexualidad, México, unAM, PAidós y PUEG, 1998, 99.

${ }^{63}$ Dentro del grupo de anormales que ocuparon la atención de instituciones, discursos y sabores desde fines del siglo XIx, Michel Foucault menciona que esta categoría se 
que había que "normalizar" o "readaptar" o bien, enviarlos al lugar más ad hoc a ellos: el prostíbulo o el manicomio. ${ }^{64}$

A diferencia de países como Francia que definió, en la ley del 28 de abril de 1832, el crimen de pedofilia como el cometido en menores de once años y que más tarde, con la ley del 13 de marzo de 1863 , se cambiara a los trece años, ${ }^{65}$ en Jalisco, este delito, no se tenía concebido como tal dentro del código penal de 1885, pero sí como se señaló anteriormente, dentro de figuras legales como la corrupción de menores, en la de la violación o en atentados contra el pudor.

Aunque en el siglo xIx, el delito de pedofilia estaba relacionado a las prácticas de los llamados "pederastas" o sodomitas (homosexuales), los expedientes judiciales y la hemerografía lo caracterizan como una desviación ejercida por los individuos de cualquier preferencia sexual y condición social.

Es conveniente agregar que tal como lo explica Jaime Humberto Borja Gómez que durante la Colonia en América Latina no se efectuó o no se conoce que se realizara una persecución a gran escala contra los llamados sodomitas, aunque sí generó un rechazo social en tres aspectos: "el rechazo religioso, un cierto miedo político y social y un desprecio a la persona", como si este tipo de preferencia sexual pudiera contaminar a la población. ${ }^{66}$

Ya en pleno siglo xIx, en Jalisco, la homosexualidad ${ }^{67}$ se encon-

formó a partir de tres figuras: El monstruo humano que cubre un sentido amplio al ser objeto de las leyes de la sociedad y las leyes de la naturaleza, más específicamente de un ámbito jurídico-biológico ( $v g r$. el hermafrodita); el individuo a corregir más asociado a las técnicas de adiestramiento y en particular a la necesidad de disciplinarlo; el onanista surgido de una estrecha relación entre su sexualidad y la organización familiar y cuya preocupación se centrara en el cuerpo y la salud. Michel Foucault, La vida de los hombres infames, Madrid, Ediciones La Piqueta, 1990, 83-91.

${ }^{64}$ Michel Foucault, Historia de la sexualidad, vol. 1-La voluntad del saber, 22a edición, México, Siglo XXI Editores, 1998, 10.

${ }^{65}$ Alain Corbin, "Entre bastidores" en Philippe Ariès y Georges Duby, Historia de la vida privada, t. 8, Madrid, Taurus Ediciones, 1991, 290.

${ }^{66}$ Jaime Humberto Borja Gómez en Osvaldo Bazán, Historia de la homosexualidad en la Argentina, Buenos Aires, Editorial Marea, 2006, 63.

${ }^{67}$ El término de "homosexualidad" surgió en Europa Occidental después de la segunda mitad del siglo XIx (en Jalisco fue más bien empleado entrado el siglo xx). Michelle Perrot señala escuetamente que el uso de esa palabra fue después de 1891, mientras que Francis Mark Mondimore señala de manera más concreta que apareció en 1869 en 
traba totalmente estigmatizada, y en ello tuvo mucho que ver el discurso aparecido en la prensa porfiriana que continuamente denostaba y señalaba a los mismos, no bajándolos de pervertidos, empleando una diversidad de adjetivos despectivos (jotos, mariquitas o ajembrados), criticando su "falta de hombría" y su proclividad al delito y creando estereotipos de carácter negativo.

$\mathrm{Al}$ igual que a las prostitutas, la prensa porfiriana llegó a justificar y a promover un clima de violencia e intolerancia contra los homosexuales, motivado por la ruptura del modelo tradicional del "ser hombre", por temor a una pretendida contaminación de orientación sexual y un escaso o deforme conocimiento sobre estas pretendidas "perversiones".

La pedofilia, asociaba, por un lado, la debilidad sexual del victimizador frente al mundo de los adultos y la fuerza total del mismo ante el de los niños, se presentaba en el porfiriato como uno de los delitos que se suponían tenían su origen en la perversión y la incontinencia, y si bien no se puede decir que fueran muy frecuentes, si se puede afirmar que se presentaban al menos periódicamente.

Los datos que se exponen en el expediente judicial presentan a la pedofilia, aunque como ya se mencionó con el nombre de otros delitos, como aquella que no sólo atentaba contra las nińas. La pedofilia afectó no sólo a niñas sino también a varones, seguramente victimizados por aquellos que habían enfrentado experiencias similares; casos criminales que por sus circunstancias unieron las limitaciones y prejuicios de la justicia penal porfiriana con las propias de la ciencia médica y psiquiátrica de fines del siglo XIX y principios del $\mathrm{xx}$ como las que se exponen en los siguientes procesos criminales:

un panfleto alemán. Otra palabra semejante a la anterior fue la de "uranismo”. El uranismo fue creado por Kart Heinrich Ulrich quien fue uno de los primeros teóricos en estudiar esta preferencia. Lo anterior no significa que no existieran otros términos populares para identificar a un hombre que tenía preferencia sexual por otro individuo de su mismo sexo. Para el término de homosexualidad véase a Michelle Perrot. "Al margen: célibes y solitarios" en Philippe Ariès y Georges Duby, Historia de la vida privada, tomo 7, Madrid, Taurus Ediciones, 1991, 303, y Francis Mark Mondimore, Una historia natural de la homosexualidad, Barcelona y Buenos Aires, Ediciones Paidós y Editorial Paidós, 1998, 21. Para uranismo véase a Bazán, op. cit., pp. 79-83, y Francis Mark Mondimore, op. cit., pp. 47-53. 


\section{Fausto e Hilario}

Un primer caso de pedofilia se presentó en noviembre del año de 1897, en la ciudad de Guadalajara, cuando la joven Amalia Medina o Amalia Chávez, de dieciséis años, soltera, de ocupación tejedora, originaria de esta ciudad y con domicilio en la calle de Águila letra " $R$ ", se presentó a denunciar en una de las comisarías, que su hermano Fausto Díaz (en realidad era su medio hermano), de cuatro años de edad, había sido violado por un muchacho.

Los hechos habían ocurrido a las cuatro y media de la tarde, cuando un joven cuyo nombre ignoraba y que habitaba en una casa de asignación (prostíbulo) llamó a su hermanito Fausto Díaz, de cuatro años de edad, y le dio un programa de cinematógrafo, posteriormente el mismo joven volvió a llamar a su hermano y lo metió al burdel y al rato salió llorando el nińo, con el pantalón anudado y diciéndole que lo habían lastimado. Amalia revisó físicamente a su hermano y observó que tenía manchas de sangre en el ano y entonces llamó a un gendarme quien se llevó preso a la Primera Comisaría al joven que había estado con Fausto. Amalia Medina no firmó por no saber escribir.

Al hacer la declaratoria, el presunto violador dijo llamarse Hilario Medina, de dieciséis años de edad, soltero, originario de Guadalajara y con habitación en la calle de Águila letra "X", negó los cargos, aduciendo que nada le había dicho al niño, que por cierto andaba jugando en la banqueta con otros muchachos y que cuando fue con él para pedirle programas del cinematógrafo ya iba llorando. Se le preguntó que como era que el niño hubiera estado corriendo y jugando si no podía caminar cuando fue a quejarse con su hermana después de haberse acercado a él, Hilario respondió que suponía que algún muchacho de los que jugaban lo había lastimado. Se le advirtió de lo imposible que era que en medio de la calle y en compañía de los muchachos se pudiera haber cometido tal falta, contestó que no sabía como habría sido. No firmó por no saber escribir.

Inmediatamente testificó el gendarme que había detenido a Hilario Medina quien señaló que cuando estaba realizando sus funciones en la esquina de su crucero, vio salir llorando al nińo Fausto 
Medina de la casa que habitaba Hilario Medina y al prestar el auxilio solicitado a Amalia Medina, el niño le informó que Hilario Medina era quien lo había lastimado, enseguida el gendarme detuvo a dicho joven. El gendarme, de nombre Albino Fernández, de veinticinco años de edad, casado y con habitación en la calle de Mora número 32, ratificó lo expuesto y no firmó por no saber.

El nińo Fausto fue examinado por un practicante de medicina, quien después de auscultarlo detenidamente comprobó sus lesiones. Hilario Medina fue remitido a la Penitenciaría Escobedo y su caso turnado al Juzgado 3o. de lo Penal; al niño Fausto Díaz se le envió al Hospital Civil en donde el personal médico de la sala de infantes confirmó las lesiones sufridas por el niño.

El Juez 3o. de lo Penal interrogó al niño quien declaró que un desconocido le había "dado un papel blanco, luego lo cogió con la pirinola [...] y que éste para realizar el acto que ejecutó, lo hizo hincarse y apoyar luego las manos al suelo" ${ }^{68}$ En el acta se registró que el interrogado apenas pudo expresarse y no contestó muchas de las preguntas.

Al ampliar su declaración, el gendarme Albino Fernández agregó que luego que fue llamado por Amalia Chávez en donde revisó al ofendido y observó que tenía sangre en el ano, ocurrió a la casa del detenido, el cual se encontraba sentado en una silla, en medio de la primera pieza, y a quien también "examinó y vio que tenía sangre en una mano y en la parte anterior de los calzoncillos; que el inculpado estaba en su casa [...] acompañado de un hermano de la señora que habita dicha casa pero este sujeto estaba dormido a causa de la embriaguez" ${ }^{69}$

Hilario Medina negó que dichas manchas en su ropa interior fueran de sangre, sino de la pintura de aceite con que había dado color a un sombrero suyo. Al ser recogidos los calzoncillos por orden del Juzgado se consideraron que las manchas que tenía de color rojizo y verde eran aparentemente de aceite.

Con los méritos anteriores el Juzgado de lo Penal declaró sujeto a prisión preventiva a Hilario Medina. Posteriormente volvió a de-

${ }^{68}$ BPEJ. SFE. AHSTJ, legajo 2935/1887, causa 137.

${ }^{69}$ Idem. 
clarar el nińo Fausto Díaz quien ratificó lo anterior ante el Juzgado y luego se le introdujo en un cuarto donde se colocó una fila de presos detenidos por delitos sexuales, en la que se encontraba Hilario Medina, y se le preguntó si entre aquellos delincuentes reconocía a quien lo había lastimado:

Díaz no contestó, pero se hace constar que sólo a Medina miraba con particular fijeza y atención, inclinándose hacia él al prevenirle que lo tocara con la mano. Habiéndosele interrogado si el procesado fue quien lo lastimó contestó afirmativamente con un signo de la cabeza. El reo insistió en su negativa; estuvo notoriamente turbado durante la diligencia y procuraba ocultarse desviando la cabeza y apartando la vista de Díaz. ${ }^{70}$

Después de revisar el caso y las pruebas presentadas, el Juzgado 3o. de lo Penal falló en contra de Hilario Medina y lo condenó a poco más de diez años de reclusión.

Del proceso criminal seguido contra Hilario Medina sobresalió el hecho de que éste habitara un cuarto de un prostíbulo tapatío por lo que al ser juzgado se le debió considerar como un individuo de malas costumbres y "mala fama"; dicha "mala fama" debió haberlo perjudicado al momento de ser juzgado y sentenciado pues no se entiende por qué un caso similar, como lo fue el de Benjamín López, éste quedara absuelto de toda culpabilidad por el delito de violación mientras que a Medina se le cargara todo el peso de la ley. ¿Por qué esas diferencias substanciales al momento de aplicar la sentencia ? La única manera de entenderlo sería reconociendo que cada juzgado realizaba una interpretación muy personal de la legislación penal o que la homofobia formaba parte de los prejuicios de ciertos jueces.

\section{En la recolección de los mezquites}

Semejante al caso anterior, pero ocurrido en el medio rural fue la violación de un niño efectuada el año de 1899 en el rancho de Los

${ }^{70}$ Idem. 
Belenes de la municipalidad de Zapopan, cuando se acusó a Benjamín López por este tipo de abuso ocurrido en la persona del niño Luis Mejía.

El proceso penal inició cuando Andrés Mejía, casado, de 41 años de edad, jornalero, originario de Nochistlán y vecino del Rancho de Los Belenes y padre del niño, presentó la denuncia correspondiente, declarando que alarmado por la tardanza de su hijo Luis, quien había salido a jugar a los alrededores, mandó a Maximiano, su otro hijo, a buscarlo y quien pudo percatarse de que su hermano estaba con Benjamín por el rumbo de un mezquite. Que al volver Luis a su casa estaba adolorido y lloroso, y una de sus amistades que estaba en la casa al momento en que regresó el niño hizo la observación de que tenía señales de sangre en la parte trasera de sus calzoncillos blancos. Luis le comentó a su hermano que Benjamín "lo había forzado y usado de su persona”, lo cual llegó a oídos de él, quien interrogó a su hijo, quien le contestó que:

Benjamín lo había cogido (tachado) a fuerzas y prometiéndole dinero y aún amagándolo con guantadas y que lo había lastimado así del ano [tachado]; siendo de notar que cuando se advirtió que Luis tenía algo de sangre, creyó el exponente que algún muchacho lo habría azotado o lesionado y al asomarse a procurar quien hubiera sido el malhechor vio que Benjamín ya estaba de vuelta en la casa. ${ }^{71}$

El padre de Luis tramitó la orden de aprehensión y la entregó a su patrón, Adolfo Venegas quien detuvo a Benjamín. Andrés Mejía presumía que efectivamente Benjamín había sido el violador pues a la hora de los hechos (al mediodía) ningún hombre o joven se encontraba en el rancho ya que todos habían salido hacia Guadalajara y Zapopan por ser domingo, añadió por último que por su parte perdonaba la injuria.

$\mathrm{Al}$ presentar su declaración, el niño Luis Mejía informó que tenía seis años de edad y que vivía en el rancho de Los Belenes. Al hacérsele la indagatoria sobre los hechos, respondió que al medio-

${ }^{71}$ BPEJ. SFE. AHSTJJ. Caja 3368, 1899, exp. 135. 
día anterior Benjamín lo había llevado por la fuerza por el rumbo de los mezquites y estando allá le propuso que le daba cinco reales porque accediera a sus deseos carnales a lo que el contestó que no sabía que era eso. Luego Benjamín lo amenazó de echarlo a un vallado e intento golpearlo y finalmente lo tumbó y lo violó. Al rato de consumada la violación lo dejó ir sin que le diera el dinero prometido, salvo unos mezquites que dejó tirados, además declaró que su hermano Maximiano había observado lo ocurrido. El Juzgado dio fe de que los calzoncillos del niño tenían manchas de sangre seca.

Benjamín López, joven de dieciocho años, soltero, jornalero, originario de la fábrica de La Escoba y vecino del rancho de Los Belenes, señaló que nunca había estado preso y negó los cargos, exponiendo que temprano en la mañana había salido a la fábrica de La Escoba a recoger provisiones y que al volver estuvo en su casa desde las once hasta las doce y cuarto, hora en la que salió junto con su madre a cierto lugar a recolectar guamuchiles, regresando a su hogar hasta las siete de la noche, y que al poco rato de su llegada fue aprehendido.

Posteriormente se realizó un acalorado careo entre Benjamín y Maximino Mejía. Maximino sostuvo que efectivamente se había reunido por un rato con ambos antes de que ellos recolectaran mezquites y que había escuchado, cuando se encontraban en un cerrito que le llamaban La Iglesia, Benjamín le preguntó a su hermano que "si este quería darle el cu... por gordas duras". Maximino recordó además que dos años atrás, cuando ambos trabajaban blanqueando uno de los salones de la fábrica de La Escoba, Benjamín le dijo que "si se dejaba, dándole a entender que para cierto acto deshonesto", lo cual el rehusó por lo que Benjamín quiso agarrarlo a la fuerza sin lograrlo, refugiándose en el salón de estampado e inmediatamente dio aviso a un encargado de nombre José María Aguilar, quien reprendió a Benjamin. Este último negó las declaraciones realizadas por Maximino. Tanto Benjamín como Maximiano no firmaron sus declaraciones por no saber escribir.

El juez de Zapopan anotó en el expediente el aspecto y las maneras del detenido: "Benjamín López parece tener un estilo como de 
afeminado". No tenía antecedentes penales. El 6 de junio de ese año, el juez de Zapopan ordenó la prisión preventiva de López. La descripción de su media filiación fue la siguiente:

Hijo de Rómulo y Juana Villalobos, estatura alta, complexión robusta, color trigueño, frente chica, pelo y cejas castańos, ojos cafés claros, nariz chica y ancha, boca regular, labios medios gruesos, imberbe, pintándole el boso [?], picado de viruela en la cara, sin tener ninguna señas particulares, viste traje de jornalero, camisa y calzón de manta blanca, remendados con manta de la misma clase, un pedazo de ceñidor colorado, corriente, usa sombrero de palma, cobija o frazada chana [sic], de cenefas coloradas en las puntas, calza huaraches y no sabe leer ni escribir. ${ }^{72}$

El juez encargado del caso ordenó el examen médico de los hermanos Mejía y de Benjamín López. El examen fue realizado por un cirujano encargado de realizar las vacunas en la villa de Zapopan quien confirmó que efectivamente Luis Mejía "presentaba equimosis en el margen del ano", mientras que el pene de Benjamín López, "de glande descubierto no presentaba alguna lesión". A Maximino Mejía no se le encontró nada en particular.

Al declararse incompetente, el juez menor de Zapopan para seguir llevando el caso, éste se traslado al Juzgado 1o. de lo Criminal del Supremo Tribunal de Justicia del Estado y al presunto criminal a la Penitenciaría Estatal. Ante el juez 1o. de lo Criminal, el agente del Ministerio Público solicitó para Benjamín López, una condena de 11 años de prisión, apoyándose en las declaraciones de la familia de Luis Mejía, en las del propio ofendido, en las vacilaciones del acusado y su fama de sodomita, por los certificados médicos y basado en el código penal vigente.

Después de analizar el expediente y realizar otras averiguaciones, el juez 1o. de lo Criminal absolvió a Benjamín López del delito de violación, considerando que no existían las pruebas suficientes. Este dictamen fue apelado por el agente del Ministerio Público, por lo que el caso pasó a un juzgado de segunda instancia. Por último, el

${ }^{72}$ Idem. 
juez 2o. de lo criminal confirmó dicha absolución y se ordenó la liberación de López el día 6 de julio de $1899 .{ }^{73}$

$\mathrm{Al}$ igual que el primer caso de pedofilia, éste tuvo por peculiaridad el haberse realizado en una zona rural, aunque cercana a la capital estatal, pero ¿por qué este tipo de delito sexual se realizaban en el campo? Seguramente el aislamiento en que se encontraban los pequeños pueblos y rancherías jaliscienses ayudaba a que los impulsos sexuales de los individuos, sobre todo de los jóvenes, se desahogaran de manera más libre que en las propias ciudades al no existir una vigilancia que pudiera abarcar y controlar todos los puntos que existían en sus proximidades, motivada quizás por la falta de control familiar propiciada por las largas jornadas laborales de los padres (de 12 a 16 horas); la ignorancia de todo tipo que existía en el campo, incluso la información sexual que seguramente era la menos propagada de todas; el nacimiento de hijos naturales o bastardos que debieron haberse criado sin disponer de un modelo masculino que favoreciera su heterosexualidad, y por último; un recalcitrante machismo en la figura paterna que distorsionara la sexualidad de los hijos y que indujera inconscientemente a la preferencia homosexual de los hijos.

De este mismo proceso criminal sobresale el reconocimiento que se hizo del presunto violador por su figura afeminada y por la dureza del lenguaje empleado al parecer por los niños y jóvenes involucrados, lo que permite suponer que se encontraban al tanto en el conocimiento de las relaciones sexuales y, además, que las prácticas homosexuales pudieran ser una constante en el medio rural.

\section{Entre lustradores de calzado}

Según Robert Buffington la homosexualidad en México, a fines del siglo XIX y principios del Xx, era considerada por los criminólogos como antinatural, antisocial y se encontraba relacionada con la criminalidad innata, además de ser contraria a los intereses políticos, económicos y sociales que implicaban la modernización del país. En

${ }^{73}$ BPEJ.SFE. AHSTJJ, caja 3368, 1908, exp. 435. 
el caso de los niños, un criminólogo del porfiriato tardío, Carlos Roumagnac, conjeturaba que aquellos que no contaban con un medio social adecuado y con las restricciones morales necesarias corrían el peligro de realizar desviaciones sexuales y delictivas. ${ }^{74}$

Algunos de los casos que se han expuesto tuvieron su explicación a partir de la fuerza y dominio del agresor frente a la debilidad de su víctima, es decir, no tuviera su razón inmediata en la raza o en la condición social, como así lo difundieran criminólogos como el mismo Roucmagnac, sino simplemente por el poder mismo que otorgan las diferencias de edad y fuerza, sumado a la presunta debilidad de los mecanismos de control social y en general a un ambiente inadecuado, los cuales en su conjunto pudieron facilitar dicho sometimiento sexual.

Un buen ejemplo que reafirma lo anterior es el ocurrido el año de 1908 en el que un adolescente fue violado en Guadalajara por varios muchachos. Los indagaciones preliminares fueron las siguientes: a raíz de la denuncia presentada por su madre, el niño José Hernández de once ańos de edad declaró que por el rumbo del parque Agua Azul y después de dejar a un amigo, un grupo de tres boleros (lustradores de calzado) lo sujetaron mientras que otros dos, conocidos con los apodos de El Mono y La Muerte, lo fornicaban.

Con la declaración del muchacho violado y la de varios de los implicados se logró armar dichos hechos: el adolescente José Hernández, de 11 años de edad, había salido de su casa por la tarde en compañía de unos muchachos nombrados "Los Tostaderos", rumbo al Agua Azul, por la Garita de Mexicaltzingo, en donde se encontraba la vía del tren que se dirigía a Ameca. Al llegar a las vías sus amigos se quedaron en ese lugar y él se dirigió con otros muchachos a una cobacha en donde jugaban baraja algunos boleros y papeleros (quienes poco antes de llegar habían estado en un lugar donde destazaban a un caballo).

Entre las cuatro y cinco de la tarde, algunos de los boleros y papeleros inducidos y atemorizados por Rafael (a) La Muerte y Alber-

${ }^{74}$ Robert Buffington, Criminales y ciudadanos en el México moderno, México, Siglo XXI Editores, 2001, passim "Los jotos. Visiones opuestas de la homosexualidad". 
to Reyes (a) El Mono, los mayores del grupo, sujetaron de pies y manos a Hernández, mientras que seis de ellos se turnaron para fornicarlo. Entre quienes lo violaron estaban El Negrito, Rafael (a) La Muerte, Teódulo Flores (a) El Ojo Pinto, Alberto Reyes (a) El Mono, El Güero y El Tovar. Rosalío Chávez fue otro de los participantes que sujetara a Hernández pero quien se negó a violarlo y Juan Muñoz quien únicamente observara los hechos y luego escapara corriendo del lugar. Para iniciar el acto sexual, El Mono forzó a El Ojo Pinto a que fuera el primero en violar a Hernández, siguiéndole después él mismo y luego el resto. Al pasar unas mujeres por el sitio en el que se encontraban dejaron de violar a Hernández, huyendo todos al momento. Estas mujeres fueron las que avisaron a la madre de Hernández acerca de lo que había ocurrido.

Después de la agresión sexual multitudinaria, los violadores se dirigieron a la Plaza de Armas de Guadalajara y al día siguiente tres de ellos fueron detenidos por la gendarmería, pero ¿quiénes fueron estos jóvenes que cometieron tales agravios en la persona de un niño? Ellos fueron: Teódulo Flores (a) El Ojo Pinto, 11 años de edad, originario de Poncitlán y vecino de Guadalajara (calle de Abrego núm. 11, vecindad de La Mora), no supo firmar; Rosalío Chávez, 15 años, soltero, bolero, originario y vecino de Guadalajara (calle de La Ladrillera núm. 12), no supo firmar; Juan Muñoz, 12 años de edad, escolar, originario y vecino de Guadalajara (calle del Huerto, vecindad del Caracol). Completan la lista Alberto Reyes (a) El Mono, papelero de 16 ańos de edad; El Tovar, bolero; Rafael (a) La Muerte y El Güero, quienes lograron escapar de la acción de la justicia.

$\mathrm{Al}$ realizarse el examen médico a José Hernández (seis días después de iniciado el proceso), los facultativos encargados de los asuntos médicos-jurídicos del Hospital Civil señalaron que no encontraron señal alguna de violación, sin embargo, agregaron, que por el tiempo transcurrido entre la fecha en la que ocurrió la agresión y la de la realización de ese examen no se podía asegurar si existió o no dicha agresión.

Los mismos médicos examinaron de sus facultades mentales a dos de los inculpados, Teódulo Flores y Juan Muñoz, dictaminando que ambos 
tienen el desarrollo de las facultades mentales correspondientes a la generalidad de las personas de su edad, clase y condición social; distinguen perfectamente las acciones buenas y malas y a nuestras preguntas investigadoras contestan con evasivas y tratando de disculpar sus faltas, haciendo recaer la gravedad de estas sobre otra persona. ${ }^{75}$

Después de realizarse todas las averiguaciones, el juez primero del Supremo Tribunal de Justicia de Jalisco absolvió del delito de violación a Teódulo Flores y a Juan Muñoz por ser menores de 14 años de edad, dejando toda responsabilidad sobre Rosalío Chávez por el delito de atentados contra el pudor, al no existir alguna prueba contundente que demostrara la violación y que tanto él como los otros dos muchachos gozaban anteriormente de buenas costumbres (no tenían antecedentes penales). A Rosalío Chávez se le castigó con una pena de un año de reclusión en establecimiento de corrección penal (la penitenciaría estatal "Antonio Escobedo). El mismo juez dejó abierta la instrucción penal para cuando se lograra la captura de Alberto Reyes o González (a) El Mono, de Rafael N. (a) La Muerte y del bolero conocido con el apodo de El Güero.

Al haber sido sumamente jóvenes, los implicados en este caso de violación, uno no deja de recordar por la reiteración de la prensa y de diversos sectores de la sociedad jalisciense sobre los peligros que representaban para ellos los vicios y las llamadas perversiones, es decir, una preocupación que al parecer no era gratuita. ¿Qué fue lo que llevó a estos niños y muchachos a cometer estos delitos? Quizás podamos afirmar que recurrir a actos homosexuales sobre todo entre adolescentes pudo ser una forma natural, fácil y sin mayor compromiso de iniciarse en la vida sexual o, como lo afirmara uno de los detenidos, una simple "travesura" ${ }^{76}$

${ }^{75}$ BPEJ. SFE, 1908, caja s/n, exp. 3963.

${ }^{76}$ Con la creación y desarrollo del psicoanálisis se ha tratado de dar una respuesta a las razones que motivan el homosexualismo. Una de ellas es la de O. Fenichel quien afirma en su Teoría psicoanalitica de la neurosis que esta orientación es mayor en la medida en que el nińo se identifique con su madre, debido a que ésta sea más brillante que la del padre, cuando éste se encuentra ausente del cuadro familiar ( $\mathrm{vgr}$. muerte, divorcio), cuando se le vincula con motivos graves (alcoholismo), excesiva severidad o violencia extrema. Citado por Manuel Puig, El beso de la mujer araña, México, Seix Barral, 1981, 141. 
Julio Guerrero, otro criminólogo mexicano, llegó a identificar en su libro La génesis del crimen en México a los papeleros, entre otros grupos marginales que además de obtener un magro salario, contar con una imagen física sucia y grotesca y una salud que se agotaba precozmente, habían perdido todos ellos "el pudor de la manera más absoluta; su lenguaje es tabernario; viven en promiscuidad sexual, se embriagan cuotidianamente $[s i c]$, frecuentan las pulquerías [...]; riñen y son los promotores principales de los escándalos" ${ }^{77}$ Eran estos mismos quienes vivían en las calles, descansaban en dormitorios públicos, "hacinados en los portales, en los quicios de las puertas, en los escombros en construcción". ${ }^{78}$

Semejante, en alguna medida, fue el de los nińos argentinos que habitaban las calles de Buenos Aires. Osvaldo Bazán explica que los llamados "canillitas" que no eran más que niños y muchachos cuyas edades oscilaban entre los 6 y 18 años y que se ocupaban de vender periódicos, el Estado aplicó sobre ellos un dispositivo de inteligencia "que no dejó nada por averiguar" y que los clasificaron en tres grandes grupos: los industriales, los adventicios y los delincuentes precoces. Entre las características que fueron mencionadas como comunes a todos ellos, estaban la masturbación, la pederastia, la homosexualidad, el onanismo y el coito recíproco. Bazán refiere al respecto: "El estudio minucioso, detallado, prejuicioso, no fue sólo un capricho intelectual del dandi que quería mostrar sus conocimientos sobre la información que en ese momento recorría el mundo. Fue un arma eficaz para el control represivo". ${ }^{79}$

Por lo pronto, el estudio de los niños y jóvenes que se expusieron como víctimas o victimarios pueden ser analizados, tal como lo observó Jacques Donzelot, a través de dos consideraciones: la primera por aquellos que se veían amenazados ("infancia en peligro"), y la segunda, por los que representaron una verdadera amenaza ("infancia peligrosa”). ${ }^{80}$

${ }^{77}$ Julio Guerrero, La génesis del crimen en México (1901), 2ª edición, México, Editorial Porrúa, 1977, 159.

${ }^{78}$ Ibidem, p. 158.

${ }^{79}$ Osvaldo Bazán, op. cit., p. 106

${ }^{80}$ Jacques Donzelot, La policía de las familias, 2a edición, Valencia, Pre-textos, $1998,84$. 


\section{Conclusiones}

La violencia en el entorno de las familias del siglo xIX y principios del xx llegó a exhibir cuadros de verdadera patología en el que se presentaban desde una violencia homicida hasta abusos sexuales y en los que las mujeres junto con los niños jugaban el papel de "víctimas inocentes" o "víctimas ideales" como así se conceptualizara a partir de la victimología. ${ }^{81}$

Las razones de esta violencia pueden pensarse en la confirmación de una cultura de este tipo que continuaba permeando a todas las clases sociales y a la misma familia en la que se toleraban ciertas dosis de violencia especialmente hacia las mujeres y niños (violencia doméstica); a la existencia de un sistema patriarcal sumamente autoritario; a la intensidad emocional y a los grados de intimidad propios de la vida familiar; y a las desigualdades de poder entre hombres y mujeres, originando a su vez una coerción que podía terminar en una violencia sexual.

En el porfiriato, el abuso sexual representó un fenómeno bastante extendido que en parte tuvo sus razones muy particulares en los problemas estructurales que vivió la sociedad, en la que no faltó la insuficiencia del aparato de justicia, la debilidad de los mecanismos de control familiar, la escasa o nula información y orientación sexual, todo ello bajo un marco discursivo que intentara inhibir las pulsiones sexuales de los adolescentes y jóvenes.

Realizado principalmente contra niños y jóvenes, este tipo de abuso era parte de las prácticas sexuales ilegítimas y antinaturales que criticaba la sociedad burguesa, y que significaba una ruptura contra el orden en la familia y el discurso moralista que se generaba

${ }^{81}$ La victimología es una ciencia penal que comprende el estudio científico de las víctimas del delito. Entre los precursores de esta ciencia se encuentran el israelí Benjamín Mendelshon y el alemán Hans von Henting. Mendelshon inició sus trabajos sobre esta nueva ciencia a fines de los cuarenta del siglo xx y fue el que acuñó el vocablo de "victimología”. Dentro de las categorías de víctimas propuestas por Mendelshon, la víctima inocente o víctima ideal es, como explica Elías Neuman, aquella "que nada ha hecho o nada ha aportado para desencadenar la situación criminal por la que se ve damnificada". Elías Neuman, Victimología, México, Cárdenas Editor y Distribuidor, 1989, 22, 27-29, 57. 
desde el propio Estado. Así también, este fenómeno representó más un abuso de carácter cultural que simplemente sexual como así lo demuestra la estadística criminal que revela la asiduidad con que se cometían estos delitos, y ello sin considerar las cifras reales que debieron de haber superado por mucho a las oficiales.

En cuanto a la sexualidad "anormal", también creó sus propios delitos particulares que como la pedofilia enfrentó un irregular tratamiento judicial; pedofilia para la que no era nada fácil encontrar un sustento legal que la reprimiera si se considera que tal delito no se encontraba tipificado con ese nombre en la codificación penal de la época. La homosexualidad no sólo fue censurada sino perseguida y fuertemente reprimida. Según José T. Laris en los primeros decenios del siglo xx la ciudad de Guadalajara ya contaba con una cárcel correccional y de reclusión para "afeminados" (antiguo templo de la Preciosa Sangre ubicado en la calle de González Ortega). ${ }^{82}$

\section{BiBLIOGRAFÍA}

ArIÉs, Philippe, El niño y la vida familiar en el Antiguo Régimen, passim capítulo I. Las edades de la vida, México, Taurus, 1998.

BÁrcena, Mariano, Ensayo estadístico de Jalisco, México, Gobierno de Jalisco, 1983.

Barragán, Esteban y Thierry Linck, "Los rincones rancheros de México", en Rancheros y sociedades rancheras, Zamora, CEMCA, El Colegio de Michoacán y orstom, 1994.

BAzÁn, Osvaldo, Historia de la homosexualidad en la Argentina, Buenos Aires, Editorial Marea, 2006.

Bourdieu, Pierre, La dominación masculina, Barcelona, Editorial Anagrama, 1999.

Bourke, Joanna, Los violadores. Historia del estupro de 1860 a nuestros dias, Barcelona, Crítica, 2009, 501.

Buffington, Robert, Criminales y ciudadanos en el México moderno, México, Siglo XXI Editores, 2001. 
Carlos V (formador), Novísima recopilación de las leyes de España recopilada y publicada por Felipe II en el año de 1567 y reimpresa en el de 1775 y en el que se incorporaron las pragmáticas cédulas, decretos, órdenes y resoluciones reales y otras providencias recopiladas $y$ expedidas hasta el año de 1804, t. v, libro XII, título XxIX. Madrid, 1805.

Castañeda, Carmen, Violación, estupro y sexualidad, Nueva Galicia 1790-1821.

Código Civil del Estado de Jalisco (1870), Guadalajara, Tipografía de S. Banda, 13 de diciembre de 1875.

Código Penal del Estado de Jalisco (1885), Guadalajara, Tipografía de la Escuela de Artes y Oficios, 1907.

Corbin, Alain, "Entre bastidores" en Phillippe Ariès y Georges Duby, dirs., Historia de la vida privada. Sociedad burguesa: aspectos concretos de la vida privada, tomo 8, Madrid, Editorial Taurus, 1991, 114-316.

Delgado, Buenaventura, Historia de la infancia, 2a edición, Barcelona, Editorial Ariel, 2000.

Doncelot, Jacques, La policía de familias, 2a edición, Valencia, España, Pre-textos, 1998.

EsCRICHE y MARTÍn, Joaquín, Diccionario razonado de legislación y jurisprudencia, vol. 1 ( Madrid, 1873), México, Cárdenas Escritor y Editor, 1991.

Flores, Francisco A., El himen en México (1885), Con/textos de Historia de la ciencia , México, Conacyt, Instituto de Investigaciones Filosóficas-unAm, 2006, 9-64.

Foucault, Michel. Historia de la sexualidad, vol. 1-La voluntad del saber, 22a edición, México, Siglo XXI Editores, 1998.

, La vida de los hombres infames, Madrid, Ediciones La Piqueta, 1990, 83-91.

Fox, Robin, La roja lámpara del incesto, passim "I. Se enciende la lámpara”, México, Fondo de Cultura Económica, 1990.

Freud, Sigmund, Tótem y tabú, Madrid, Alianza, 1999.

Galindo, Miguel, Apuntes sobre la higiene en Guadalajara, Tesis de recepción presentada ante la Facultad de Medicina de Guadalajara, Guadalajara, 1908, 266. 
2), Guadalajara, 1908, 187.

GonzÁlez NaVarro, Moisés, "Moral social" en Daniel Cosío Villegas, coord., Historia moderna de México. La República Restaurada. Vida social, 4a. edición, México, enero de 1993.

LARIs, José T., Guadalajara de Indias, Guadalajara, s.e., 1945.

Mancilla Villa, Martha Lilia, Locura y mujer durante el porfiriato, México, Editorial del Círculo Psicoanalítico Mexicano, 2001.

Mondimore, Francis Mark, Una historia natural de la homosexualidad, Barcelona y Buenos Aires, Ediciones Paidós y Editorial Paidós, 1998.

Monsivárs, Carlos, "Prólogo" en Ava Vargas (colección de fotografías), La casa de citas en el barrio galante, México, Grijalbo y Conaculta, 1991, IX.

Neuman, Elías, Victimología, México, Cárdenas Editor y Distribuidor, México, 1989.

Ortega Noriega, Sergio, "El discurso teológico de Santo Tomás de Aquino sobre el matrimonio, la familia y los comportamientos sexuales" en El placer de pecar y el afán de normar, Seminario de Historia de las Mentalidades, Joaquín Mortíz e INAH, 1987, 15-78. Pérez Mora, Marco Antonio, "La pedofilia es resultado del miedo" en Público (Sección Cultura y Tendencias), Guadalajara, núm. 1596, domingo 3 de febrero de 2002, 6 .

Perrot, Michelle, "Al margen: célibes y solitarios" en Philippe Ariès y Georges Duby, Historia de la vida privada, tomo 7, Madrid, Taurus Ediciones, 1991, 293-309.

Pitt-Rivers, Julian, Antropología del honor o politicas de los sexos, España, Grupo Editorial Grijalbo, 1979.

Platt, Anthony M., Los "Salvadores del Niño" o la invención de la delincuencia, 4á. edición, Siglo XXI Editores, 2001.

Puig, Manuel, El beso de la mujer araña, México, Seix Barral, 1981.

Radkau, Verena, Por la debilidad de nuestro ser. Mujeres del pueblo en la paz porfiriana, México, Cuadernos de la Casa Chata, Ciesas, 1989.

Ramos Escandón, Carmen, "La nueva historia, el feminismo y la mujer" en Carmen Ramos Escandón, comp., Género e historia. 
La historiografia sobre la mujer, México, Instituto Mora y Universidad Autónoma Metropolitana, 1997, 7-37.

Rivera Garretas, María Milagros, Nombrar el mundo en femenino. Pensamiento de las mujeres y teoría feminista, España, Icaria Editorial, 1994.

Rodríguez, Pablo y María Emma Mannarelli, Historia de la infancia en América Latina, Colombia, Universidad del externado de Colombia, 2007.

Roucmagnac, Carlos, Los criminales en México. Ensayo de criminología criminal, México, Tipografía El Fenix, 1904.

Sosenski, Susana, Niños en acción. El trabajo infantil en la ciudad de México, 1920-1931, México, El Colegio de México, 2010.

Speckman, Elisa, "Las flores del mal. Mujeres criminales en el porfiriato" en revista Historia Mexicana, núm. xvII, México, Colegio de México, 1997, 183-229.

, Crimen y castigo. Legislación penal, interpretaciones de la criminalidad y administración de la justicia (Ciudad de México, 1872-1910), México, El Colegio de México y unam, 2002.

Stern, Steve J., La historia secreta del género, México, Fondo de Cultura Económica, 1999.

Thornhill, Randy y Craig T. PAlmer, Una historia natural de la violación. Los fundamentos biológicos de la coersión sexual, México, Editorial Océano, 2006.

Trujillo Bretón, Jorge Alberto, La prostitución en Guadalajara durante la crisis del porfiriato (1877-1911), Tesis para obtener el grado de licenciado en historia (inédita), Guadalajara, Facultad de Filosofía y Letras de la Universidad de Guadalajara, 1992.

"Miguel Galindo y la Ciudad del Polvo" en Revista del Seminario de Historia Mexicana, Guadalajara, Universidad de Guadalajara y Universidad Autónoma de Puebla, época 1, vol. 1, núm. 2, invierno de 1997, 79-111.

, Gentes de Trueno. Moral social, criminalidad y violencia cotidiana en el Jalisco porfiriano (1876-1911), Guadalajara, presentada en el ciesas de Occidente, inédita, 1999.

,"La sociedad del buen tono" en revista Graffylia, Puebla, Facultad de Filosofía y Letras de la Benemérita Universidad Au- 
tónoma de Puebla, año 6, número 8-9, primavera-otoño, 2008, 152-161.

VIGarello, Georges, Historia de la violación, siglos XVI-XX, Madrid, Ediciones Cátedra, 1999.

Weeks, Jeffrey, Sexualidad, México, unAM, PAIDós y PUeG, 1998.

FECHA DE RECEPCIÓn DEL ARTíCUlo: 7 de septiembre de 2009 FECHA DE ACEPTACIÓN Y RECEPCIÓN DE LA VERSIÓN FINAL: 31 de enero de 2011 